\title{
SISTEM PAKAR DIAGNOSA KEKURANGAN VITAMIN PADA TUBUH MANUSIA BERBASIS WEB
}

\author{
Ai Ilah Warnilah \\ Sistem Informasi \\ AMIK BSI Tasikmalaya \\ Jalan Tanuwijaya No.4 Tasikmalaya \\ ai.aiw@bsi.ac.id
}

\begin{abstract}
Along with the development of technology, also developed a system thet is able to adopt technology and the humant human thinking procces is an expert system which contains specific knowledge so that everyone can use to solve a specific problem, in this case is the health problem with vitamin deficiency in the human body. When there is a health disoreder, especially vitamin deficiency rether the people will a come to a doctor or nutritionist for a consultation. Sometimes there are also weaknes when entrusting to specialist such as limited hours of practice and the events that forced many patients have to queue and require a sizeeable fee. In this case, we as the people who use the service need more of an expert who can faciliate in the diagnosis of vitamin deficiency in the body as early prevention. Therefore as an alternative solution is to create an expert sysem aplication that can identify / diagnose a vitamin deficiency based on body sympton with forward chaining methode. Displayed in the form of a website using PHP programing with MYSQL database, so the consultation will be easeier, cost-eeffective and can be used anytime, anywhere.
\end{abstract}

Keywords : Expert system, Deficiency, Forward chaining

\begin{abstract}
Abstrak - Seiring perkembangan teknologi,dikembangkan pula suatu sistem teknologi yang mampu mengadopsi proses dan cara berpikir manusia yaitu sistem pakar yang mengandung pengetahuan tertentu sehingga setiap orang dapat menggunakan untuk memecahkan masalah yang bersifat spesisfik, dalam hal ini adalah permasalahan kesehatan menangani kekurangan vitamin pada tubuh manusia. Masalah kesehatan khususnya kekurangan vitamin lebih tepatnya orang akan datang ke dokter atau ahli gizi untuk berkonsultasi. Namun terdapat kelemahan jika memepercayakan kepada dokter ahli seperti terbatasnya jam praktek dan kejadian banyak pasien yang memaksa harus harus melakukan antrian serta memerlukan biaya yang lumayan besar. Dalam hal ini, kita selaku orang yang menngunakan jasa lebih membutuhkan seorang pakar yang bisa memudahkan dalam mendiagnosa kekurangan vitamin dalam tubuh sebagai pencegahan awal. Dengan demikian sebagai alternatif pemecahan masalah yaitu dengan membuat aplikasi sistem pakar yang dapat megidentifikasi/mendiagnosa kekurangan vitamin pada tubuh berdasarkan gejala yang ada menggunakan metode forward chaining. Yang ditampilkan dalam bentuk website menggunakan program php dengan database MySQL, sehingga konsultasi akan lebih mudah, hemat biaya serta dapat digunakan kapan dan dimana saja.
\end{abstract}

Kata Kunci : Sistem Pakar, Vitamin, Forward Chaining 


\section{PENDAHULUAN}

Kesehatan adalah harta yang paling berharga. Menurut badan kesehatan dunia yang dinaungi PBB yaitu WHO (World health Organization) yang di maksud sehat adalah suatu kondisi sejahtera jasmani, rohani, serta sosial ekonomi. Berberapa faktor yang mempengaruhi kesehatan manusia diantaranya udara, air, olah raga yang teratur, istirahat yang cukup, keseimbangan emosi, yang paling terpenting salah satunya makanan dan minuman. Pola makan dengan megkonsumsi makanan yang memenuhi gizi seimbang merupakan salah satu faktor untuk terhindar dari penyakit. Salah satu gizi yang harus kita perhatikan keberadaanya dalam tubuh adalah vitamin.

Dewasa ini ketika terjadi gangguan kesehatan khususnya kekurangan vitamin lebih tepatnya orang akan berkonsultasi dengan dokter ahli atau dengan orang yang sudah mengetahui banyak tentang kesehatan, walaupun demikian terkadang terdapat kelemahan bila mempercayakan kepada dokter ahli seperti terbatasnya jam kerja/praktek atau banyaknya pasien sehingga memaksa harus melakukan antrian, selain itu bagi yang tingkat ekonominya lemah juga akan menjadi masalah, karena konsulltasi dengan dokter tidak cukup murah.

Vitamin merupakan suatu zat senyawa kompleks yang berfungsi untuk membantu pengaturan atau proses kerja tubuh. Zat ini sangat penting untuk melakukan aktifitas, karena bila tubuh kekurangan vitamin akan membuat tubuh rentan terhadap penyakit. Dengan adannya permasalahan diatas dalam penelitian ini penulis tertarik untuk memilih judul:"Sistem Pakar Diagmosa Kekurangan Vitamin Pada Tubuh Manusia Berbasis Web"

\section{METODE PENELITIAN}

\section{Ruang Lingkup}

Untuk membatasi objek yang menjadi pokok penelitian maka penulis membatasi permasalahan sebagai berikut:
1. Proses yang penulis gunakan inferensi penalaran maju (forward chaining

2. Untuk saat ini vitamin yang digunakan antara lain vitamin $\mathrm{A}, \mathrm{B} 1$, B2, B3, B5, B6, B12, C, D, E dan K. Adapun untuk pengembangan system pakar supaya semakin cerdas disediakan ruang admin untuk mengelola dan maintenance system, dimana sumber pengetahuan diperoleh dari pakar, buku- buku dan e-book yang mendukung terhadap permasalahan yang penulis ambil

3. Perancangan data sistem pakar ini terdapat data fungsi solusi, anjuran konsumsi dan saran pengolahan vitamin yang disediakan dalam bentuk tabel

4. Sistem pakar ini menggunakan Bahasa pemrogaman PHP dan database MYSQL

\section{Metode Penelitian}

Adapun metode penelitian yang digunakan pada penelitian ini adalah sebagai berikut:

\section{Analisis}

1. Metode Studi Pustaka

Pada metode ini penulis melakukan pencarian, pembelajaran dari berbagai macam literature dan pengumpulan data, bahan-bahan tertulis dengan cara mempelajari serta membaca buku-buku, tabloid, majalah, artikel, dan media lain yang berhubungan dengan pembahasan masalah yang akan siuraikan dalam menunjnag penelitian inin sebagai sumber informasi yang berkaitan dengan judul.

2. Wawancara (Interview)

Penulis melakukan sesuatu metode tanya jawab mengenai semua hal yang berhubungan dengan nutrisi vitamin pada tubuh manusia kepada bagian yang ahli dalam kesehatan khususnya tentang gizi/nutrisi vitamin antara lain dokter ataupun akademisi ilimu gizi 


\section{Perancangan}

1. Perancangan Basis Data dan hubungan antara entitas yang timbul secara konseptual dengan ERD(Entitas Relationship Diagram)

2. Perancangan Proses atau fungsi dengan DFD (Data Flow Diagram)

3. Perancangan Antar Muka

\section{Implementasi}

1. Relationship Database Manajemen Sistem (RDBMS) menggunakan MySQL.

2. Alat Pengembangan yang digunakan adalah PHP dan Apache2triad

\section{Tujuan Penelitian}

Tujuan penelitian membuat aplikasi sisitem pakar diagnose kekurangan vitamin pada tubuh manusia ini memiliki tujuan sebagai berikut:

1. Membuat suatu program system pakar yang berisi pengetahuan dari seorang pakar yang memiliki kemampuan dapat mendiagnosa kekurangan vitamin dari gejalagejala yang dirasakan oleh Penderita

2. Dengan adanya aplikasi system pakar ini diharapkan bisa membantu penderita/pengguna untuk mengetahui gejala-gejala tubuh yang dialami untuk mendiagnosa kekurangan vitamin. Sehingga nantinya akan ditampilkan Kesimpulan dan solusi kekurangan vitamin dari permasalahan yang dialami oleh masing-masing penderita.

\section{PEMBAHASAN}

\section{Analisis dan Perancangnan Domain Expert}

\section{Proses Inferensi Penalaran Maju (Forward Chaining)}

Suatu kaidah disusun berdasarkan pengetahuan dibagi menjadi dua bagaian utama, yaitu bagian fakta dan bagian kesimpulan. Selanjutnya bagian fakta sendiri dikelompokan lagi menjadi faktafakta yang lebih spesifik untuk kemudian masing-masing kelompok fakta akan membentuk sebuah kaidah yang memiliki sebuah kesimpulan tertentu. Untuk menjelaskan bagaimana aliran proses jika menggunakan metoda forward chaining dapat dilihat pada model berikut :

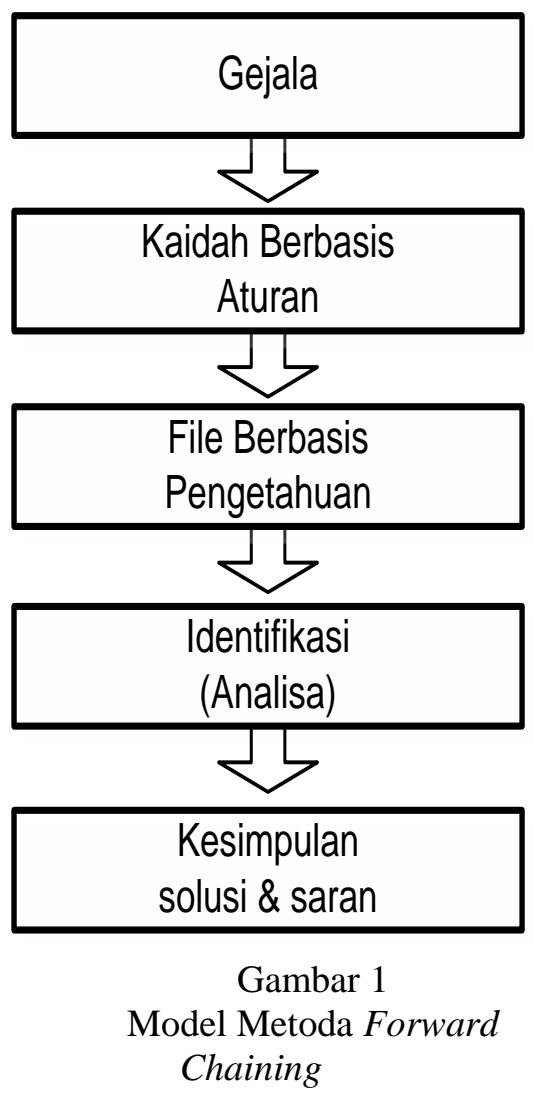

Dari model tersebut, dapat dijelaskan langkah-langkah proses inferensi penalaran maju (forward chaining) yang dilakukan adalah sebagai berikut :

Masukan berupa fakta yang diberikan oleh user adalah data user, gejala yang tampak. Kemudian data-data tersebut disusun ke dalam kaidah berbasis aturan, dimana setelah itu terjadi pengecekan apakah kaidah-kaidah tersebut sesuai atau tidak. Jika tidak maka user akan kembali mengisikan fakta-fakta yang lain, akan tetapi jika kaidah tersebut sesuai maka, kaifah atau fakta tersebut tersimpan didalam file berbasis data yang kemudian diproses hingga user bisa melakukan proses identifikasi.

Dari identifikasi tersebut, akan terlihat gejala yang dimaksudkan menghasilkan suatu kesimpulan tentang vitamin. Dan diakhir program akan 
dihasilkan sebuah kesimpulan dan solusi sesuai dengan jenis gejala kekurangan vitamin.

\section{Analisa Basis Pengetahuan (Knowledge Base)}

Dalam pembangunan sistem berbasis pengetahuan, pengetahuan yang telah diekstrak dipersentasikan kedalam bentuk yang dapat diproses oleh komputer. Representasi pengetahuan merupakan kombinasi sistem berdasarkan dua elemen, yaitu struktur data dan penafsiran prosedur yang digunakan sebagai pengetahuan untuk menyimpan struktur data.

Basis pengetahuan ini merupakan inti program dari sistem pakar dimana basis pengetahuan ini merupakan representasi pengetahuan (Knowledge Representation) dari seorang pakar.

Analisa perancangan data-data vitamin dan gejala klinis pada tubuh secara lengkap dapat dilihat pada pembahasan berikut ini:

1.Vitamin A

Gejala klinisnya:

a. Mata rabun senja

b. Kulit tidak sehat

c. Gangguan pernapasan

d. Nafsu makan berkurang

e. Kerusakan gigi

f. Kurang darah

g. Gangguan pertumbuhan

2. Vitamin B1

Gejala klinisnya:

a. Nafsu makan berkurang

b. Mudah cape/lelah

c. Beri-beri

d. Depresi

e. Irama jantung tidak normal

3.Vitamin B2

Gejala klinisnya:

a. Depresi

b. Tidak tahan terhadap cahaya

c. Bibir pecah-pecah

4. Vitamin B3

Gejala klinisnya:

a. Kulit tidak sehat

b. Depresi

c. Gangguan pencernaan

d. Diare

e. Sariawan

f. Otot mudah keram g. Muntah

h. Badan lemah/cape

5.Vitamin B5

Gejala klinisnya:

a. Kulit tidak sehat

b. Gangguan pernafasan

c. Sakit kepala

d. Muntah

e. Otot kejang-kejang

f. Rambut cepat beruban

g. Susah tidur

h. Kesemutan

i. Badan lemah/letih

6.Vitamin B6

Gejala klinisnya:

a. Kulit tidak sehat

b. Kurang darah

c. Gangguan pertumbuhan

d. Otot kejang-kejang

e. Susah tidur

f. Bdan lemah/letih

g. Daya tahan tubuh lemah

7.Vitamin B12

Gejala klinisnya:

a. Kurang darah

b. Mudah cape/lelah

c. Gangguan pencernaan

d. Gangguan sistem syaraf

8.Vitamin C

Gejala klinisnya:

a. Nafsu makan berkurang

b. Mudah cape/lelah

c. Sariawan

d. Otot mudah keram

e. Kulit kering

f. Nyeri pada persendian

g. Gusi berdarah

h. Nafas pendek

i. Rambut rontok

9.Vitamin D

Gejala klinisnya:

a. Kerusakan gigi

b. Otot kejang-kejang

c. Pertumbuhan tulang tidak normal

10. Vitamin E

Gejala klinisnya:
a. Kurang Darah
b. Gangguan sistem syaraf
c. Kemandulan

11.Vitamin K

Gejala klinisnya:

a. Pendarahan dalam tubuh Dalam Perancangan data sistem pakar ini terdapat 
data fungsi solusi, anjuran

konsumsi dan saran pengolahan vitamin. Dapat dilihat pada tabel-tabel berikut ini:

Tabel 1

Fungsi dan Solusi Kekurangan Vitamin

\begin{tabular}{|c|c|c|}
\hline Vitamin & Fungsi & Solusi \\
\hline $\mathrm{A}($ Retional $)$ & $\begin{array}{l}\text { Proses penglihatan, } \\
\text { membantu reproduksi tulang } \\
\text { dan gigi, kesehatan kulit, } \\
\text { mencegah infeksi, } \\
\text { pertumbahan serta mencegah } \\
\text { kanker. }\end{array}$ & $\begin{array}{l}\text { Perbanyak makan sayuran } \\
\text { berwarna hijau tua(daun } \\
\text { singkong, pepaya, kemangi, } \\
\text { bayam), wortel, pepaya, melon, } \\
\text { pisang, mangga, susu, keju, } \\
\text { mentega, ikan dan hati. }\end{array}$ \\
\hline $\begin{array}{c}\text { B1 } \\
\text { (Thiamin) }\end{array}$ & $\begin{array}{lr}\begin{array}{l}\text { Metabolisme } \\
\text { karbohidrat,dan }\end{array} & \text { protein, } \\
\text { glukosa, } & \text { mood, } \\
\text { meningkatkan } & \text { mesemutan, } \\
\text { meringankan } & \text { asetilkolin } \\
\text { sintesis } & \text { berhubungan dengan syaraf, } \\
\text { anti stres dan membantu } \\
\text { jantung memompa darah. }\end{array}$ & $\begin{array}{l}\text { Pebanyak makan biji-bijian } \\
\text { seperti gandum, kacang- } \\
\text { kacangan, beras merah, kedelai } \\
\text { serta telur,daging sapi, ayam, } \\
\text { hati, susu, dan keju. }\end{array}$ \\
\hline $\begin{array}{c}\text { B2 } \\
\text { (Riboflavin) }\end{array}$ & $\begin{array}{l}\text { Perbanyak makan susu, hati, } \\
\text { keju, ikan, kuning telur, } \\
\text { brokoli, jamur, bayam, anggur } \\
\text { dan serealia }\end{array}$ & $\begin{array}{l}\text { Perbanyak makan susu, hati, } \\
\text { keju, ikan, kuning telur, brokoli, } \\
\text { jamur, bayam, anggur dan } \\
\text { serealia }\end{array}$ \\
\hline B3(Niacin) & 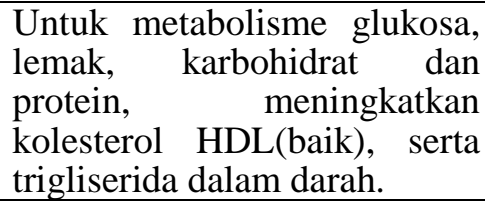 & $\begin{array}{l}\text { Perbanyak makan hati, daging } \\
\text { ayam, itik, susu, telur, kacang } \\
\text { tanah, dan serealia (beras, } \\
\text { jagung). }\end{array}$ \\
\hline $\begin{array}{l}\text { B5 (Asam } \\
\text { Pantotenat) }\end{array}$ & $\begin{array}{l}\text { Berperan metabolisme energi } \\
\text { dari karbohidrat, protein dan } \\
\text { lemak, berperan dalam } \\
\text { pengeluaran hormon adrenal } \\
\text { serta pembentukan antibodi. }\end{array}$ & $\begin{array}{l}\text { Berperan metabolisme energi } \\
\text { dari karbohidrat, protein dan } \\
\text { lemak, berperan dalam } \\
\text { pengeluaran hormon adrenal } \\
\text { serta pembentukan antibodi. }\end{array}$ \\
\hline $\begin{array}{c}\text { B6 } \\
\text { (Piridoksin) }\end{array}$ & $\begin{array}{l}\text { Berperan penting dalam } \\
\text { metabolisme asam amino \& } \\
\text { lemak, juga berperan dalam } \\
\text { produksi sel darah merah, } \\
\text { serta menjaga kesehatan kulit, } \\
\text { syaraf, dan jaringan tubuh. }\end{array}$ & $\begin{array}{l}\text { Perbanyak makan telur, daging, } \\
\text { ikan, unggas, kentang, kubis, } \\
\text { sayuran hijau, pisang dan buah } \\
\text { berwarna ungu. }\end{array}$ \\
\hline $\begin{array}{c}\text { B12 } \\
\text { (Kobalamin) }\end{array}$ & $\begin{array}{l}\text { Berperan penting dalam } \\
\text { metabolisme purin dan } \\
\text { primidin, dibutuhkan dalam } \\
\text { sintesis mielin dalam serabut } \\
\text { syaraf, pematangan sel darah } \\
\text { merah. }\end{array}$ & $\begin{array}{l}\text { Perbanyak makan telur, hati dan } \\
\text { daging ayam, sapi, perbanyak } \\
\text { minum susu, yoghurt/bahan } \\
\text { permentasi lainya. }\end{array}$ \\
\hline $\begin{array}{c}\text { C } \\
\text { (Asam } \\
\text { Askorbat) }\end{array}$ & $\begin{array}{l}\text { Sebagai anti } \begin{array}{l}\text { oksidan, } \\
\text { pembentukan }\end{array} \text { kolagen, } \\
\text { meningkatkan ketahanan } \\
\text { tubuh terhadap infeksi, anti } \\
\text { alergi, membangun sistem } \\
\text { kekebalan tubuh dan } \\
\text { membantu tubuh menyerap } \\
\text { zat besi. }\end{array}$ & $\begin{array}{l}\text { Perbanyak makan buah-buahan } \\
\text { seperti jeruk, kiwi, strawberry, } \\
\text { melon, jambu batu, pepaya, } \\
\text { semangka, nanas, brokoli, daun } \\
\text { katuk, kelor, melinjo, singkong, } \\
\text { talas, kubis, dan tomat. }\end{array}$ \\
\hline
\end{tabular}


Lanjutan Tabel 1

Fungsi dan Solusi Kekurangan Vitamin

\begin{tabular}{|c|c|c|}
\hline $\begin{array}{c}\text { D } \\
\text { (Kalsiferol) }\end{array}$ & $\begin{array}{l}\text { Bekerja pada mineralisasi } \\
\text { tulang dengan meningkatkan } \\
\text { penyerapan kalsium dan } \\
\text { posfor didalam pencernaan, } \\
\text { sehingga kadar darah } \\
\text { meningkat. }\end{array}$ & $\begin{array}{l}\text { Usahakan tubuh terkena sinar } \\
\text { matahari dari jam 7-9 pagi, } \\
\text { perbanyak makan ikan salmon, } \\
\text { ikan sarden, kning telur, susu, } \\
\text { minyak jagung dan margarine. }\end{array}$ \\
\hline $\begin{array}{c}\mathrm{E} \\
\text { (Tokoferol) }\end{array}$ & $\begin{array}{lr}\text { Sebagai } & \text { antioksidan, } \\
\text { membantu } & \text { menstabilkan } \\
\text { membran sel, mencegah } & \text { menceran } \\
\text { tumbuhnya tumor, mengatur } \\
\text { reaksi oksidasi dan } \\
\text { melindungi vitamn A serta } \\
\text { berpengaruh besar terhadap } \\
\text { sel. }\end{array}$ & $\begin{array}{l}\text { Perbanyak makan sayuran, } \\
\text { minyak kacang, minyal kulit } \\
\text { gandum, minyak jagung, minyak } \\
\text { biji matahari, ikan, kecambah, } \\
\text { ragi, mentega, dan telur. }\end{array}$ \\
\hline K (Filokuinona) & $\begin{array}{lr}\text { Merupakan unsur } & \text { penting } \\
\text { untuk sintesis beberapa } \\
\text { protein termasuk runtuk } \\
\text { pembekuan } & \text { darah. } \\
\text { Mengkatalis } & \text { reaksi } \\
\text { karboksilasi atom karbon } \\
\text { residu asam glutamat pada } \\
\text { protein tertentu. }\end{array}$ & $\begin{array}{l}\text { Perbanyak makan hati, sayur- } \\
\text { sayuran berwarna hijau dan } \\
\text { berdaun banyak, seperti bayam, } \\
\text { katuk, kol, selada dan brokoli, } \\
\text { kubis, kuning telur dan susu. }\end{array}$ \\
\hline
\end{tabular}

Tabel 2

Anjuran Konsumsi dan Saran Pengolahan Vitamin

\begin{tabular}{|c|c|c|}
\hline Vitamin & Anjuran konsumsi & Saran Pengolahan \\
\hline A & $1998 \mathrm{IU}$ & $\begin{array}{l}\text { Apabila mengolah makanan } \\
\text { hindarkan dari pemasakan } \\
\text { terlalu lama cukup setengah } \\
\text { matang. Buah-buahan } \\
\text { merupakan sumber vitamin A } \\
\text { yang baik. }\end{array}$ \\
\hline B1 & $1,0 \mathrm{mg}$ per hari & $\begin{array}{l}\text { Masak dengan suhu } \\
\text { tidak terlalu panas dan jangan } \\
\text { terlalu lama. Hindarkan } \\
\text { perendaman dalam air \& } \\
\text { jauhkan dari udara terbuka. }\end{array}$ \\
\hline B2 & $1,2 \mathrm{mg}$ per hari & $\begin{array}{l}\text { Saat mengolah } \\
\text { makanan sumber vitamin B2 } \\
\text { hindarkan dari perendaman air } \\
\text { dan jauhkan dari cahaya }\end{array}$ \\
\hline B3 & $15 \mathrm{mg}$ perhari & $\begin{array}{l}\text { Saat mengolah makanan } \\
\text { hindarkan dari perendaman air } \\
\text { dan masak dengan jumlah air } \\
\text { tidak terlalu banyak. }\end{array}$ \\
\hline B5 & - & $\begin{array}{l}\text { Saat mengolah makanan } \\
\text { hindarkan dari perendamanair } \\
\text { dan masak dengan jumlah air } \\
\text { tidak terlalu banyak dengan } \\
\text { suhu tidak terlalu tinggi. }\end{array}$ \\
\hline
\end{tabular}


Lanjutan Tabel 2

Anjuran Konsumsi dan Saran Pengolahan Vitamin

\begin{tabular}{|c|c|c|}
\hline B6 & $1,3 \mathrm{mg}$ per hari & $\begin{array}{l}\text { Saat mengolah makanan } \\
\text { hindarkan dari perendaman air } \\
\text { dan masak dengan jumlah air } \\
\text { tidak terlalu banyak. }\end{array}$ \\
\hline B12 & $2,4 \mathrm{mg}$ per hari & $\begin{array}{l}\text { Apabila memasak hindarkan } \\
\text { dari perendaman dalam air } \\
\text { dan masak dengan jumlah air } \\
\text { tidak terlalu banyak. }\end{array}$ \\
\hline $\mathrm{C}$ & - & $\begin{array}{l}\text { Apabila memasak hindarkan } \\
\text { dari perendaman dalam air. } \\
\text { Mengolah buah sumber } \\
\text { vitamin C simpan pada suhu } \\
\text { dingin dan hindarkan dari } \\
\text { udara dan cahaya. }\end{array}$ \\
\hline $\mathrm{D}$ & $400 \mathrm{IU}$ & $\begin{array}{l}\text { Dalam proses pemasakan } \\
\text { makanan hindarkan dari suhu } \\
\text { yang terlalu tinggi dan } \\
\text { pemasakan yang terlalu lama. } \\
\text { Tutup/hindarkan dari terbuka } \\
\text { atau cahaya. }\end{array}$ \\
\hline E & $15 \mathrm{IU}$ & $\begin{array}{l}\text { Pada saat mengolah makanan } \\
\text { sumber vitamin E jauhkan } \\
\text { dari udara terbuka dan cahaya } \\
\text { matahari. }\end{array}$ \\
\hline K & - & $\begin{array}{l}\text { Saat pengolahan, jauhkan } \\
\text { makanan sumber vitamin K } \\
\text { dari cahaya, asam, alkali, dan } \\
\text { agen oksidasi agar tidak } \\
\text { rusak. }\end{array}$ \\
\hline
\end{tabular}

\section{Perancangan Pohon Keputusan Identifikasi Kekurangan Vitamin}

Diagram pohon keputusan merupakan suatu rancangan yang diginakan untuk membangun sebuah sistem pakar, di dalam diagram agar pohon keputusan tersebut akan dicari solusi hasil akhir dari setiap pemeriksaan. Diagram pohon keputusan akan mempermudah untuk menyusun basis pengaturan dan aturan serta menentukan penelusuran dari setiap pelaksanaan identifikasi gejala kekurangan vitamin. 


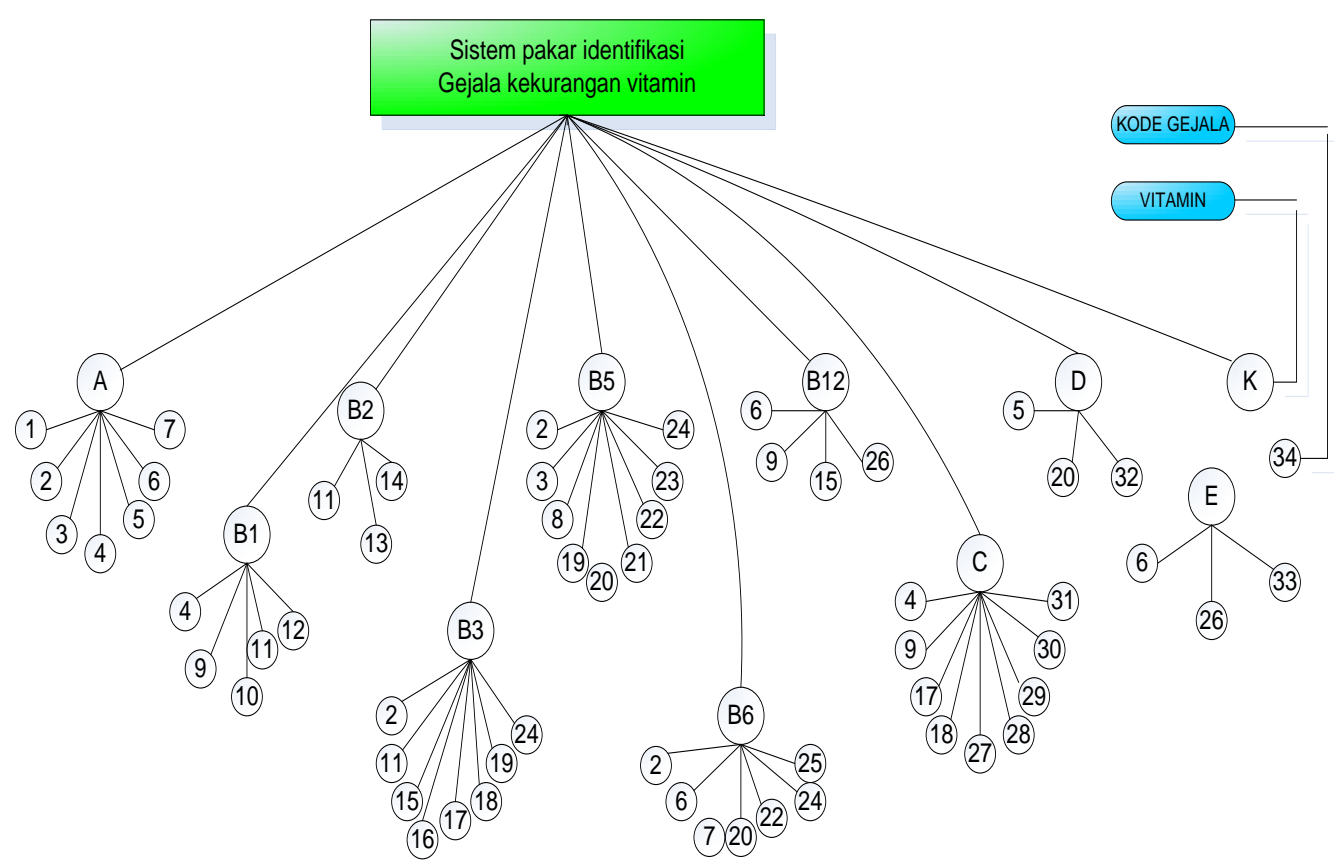

Gambar 2

Diagram Pohon Penelusuran

\section{Pembentukan Rule}

Aturan dibuat berdasarkan diagram pohon keputusan yang telah dibuat sebelumnya. Dengan rule dapat dengan mudah mengetahui hasil akhir nanti berdasarkan rule-rule yang ada. Berikut adalah keterangan dari pohon keputusan

Tabel 3

Aturan/Rule

\begin{tabular}{cl}
\hline $\begin{array}{c}\text { Jenis Kekurangan } \\
\text { Vitamin }\end{array}$ & \multicolumn{1}{c}{ Gejala } \\
\hline (1)Vitamin A & (1) Mata Rabun Senja \\
& (2) Kulit Tidak Sehat \\
& (3) Gangguan Pernafasan \\
& (4) Nafsu Makan Berkurang \\
& (5) Kerusakan Gigi \\
& (6) Kurang Darah \\
& (7) Gangguan Pertumbuhan \\
& (4) Nafsu makan berkurang \\
& (9) Mudah cape/lelah \\
& (10) Beri-beri \\
& (11) Depresi \\
& (12) Irama jantung tidak normal \\
& (11) Depresi \\
& (13) Tidak tahan terhadap cahaya \\
& (14) Bibir pecah-pecah \\
\hline
\end{tabular}


Lanjutan Tabel 3

Aturan/Rule

\begin{tabular}{|c|c|}
\hline (4)Vitamin B3 & $\begin{array}{l}\text { (2) Kulit tidak sehat } \\
\text { (11) Depresi } \\
\text { (15) Gangguan perncernaan } \\
\text { (16) Diare } \\
\text { (17) Sariawan } \\
\text { (18) Otot mudah keram } \\
\text { (19) Muntah } \\
\text { (24) Badan lemah/letih }\end{array}$ \\
\hline (5) Vitamin B5 & $\begin{array}{l}\text { (2) Kulit tidak sehat } \\
\text { (3) Gangguan pernafasan } \\
\text { (4) Sakit kepala } \\
\text { (19) Muntah } \\
\text { (20) Otot kejang-kejang } \\
\text { (21) Rambut cepat beruban } \\
\text { (22) Susah tidur } \\
\text { (23) Kesemutan } \\
\text { (24) Badan lemah/letih }\end{array}$ \\
\hline (6) Vitamin B6 & $\begin{array}{l}\text { (2) Kulit Tidak sehat } \\
\text { (6) Kurang darah } \\
\text { (7) Ganggaun pertumbuhan } \\
\text { (20) Otot kejang-kejang } \\
\text { (22) Susah tidur } \\
\text { (24) Badan lemah/letih } \\
\text { (25) Daya tahan tubuh menurun }\end{array}$ \\
\hline (7) Vitamin B12 & $\begin{array}{l}\text { (6) Kurang darah } \\
\text { (9) Mudah cape/lelah } \\
\text { (15) Gangguan pencernaan } \\
\text { (26) Gangguan sistem syaraf }\end{array}$ \\
\hline (8) Vitamin C & $\begin{array}{l}\text { (4) Nafsu makan berkurang } \\
\text { (9) Mudah cape/lelah } \\
\text { (17) Sariawan } \\
\text { (18) Otot mudah keram } \\
\text { (27) Kulit kering } \\
\text { (28) Nyeri pada persendian } \\
\text { (29) Gusi berdarah } \\
\text { (30) Nafas pendek } \\
\text { (32) Rambut rontok }\end{array}$ \\
\hline (9) Vitamin D & $\begin{array}{l}\text { (5) Keruskan gigi } \\
\text { (20) Otot kejang-kejang } \\
\text { (32) Pertumbuhan tulang tidak normal }\end{array}$ \\
\hline (10) Vitamin E & $\begin{array}{l}\text { (6) Kurang darah } \\
\text { (26) Gangguan sistem syaraf } \\
\text { (33) Kemandulan }\end{array}$ \\
\hline (11) Vitamin K & (34) Pendarahan dalam tubuh \\
\hline
\end{tabular}




\section{Analisis dan Perancangan Perangakat Lunak}

\section{Metode Analisis Peranglat Lunak}

Salah satu pendekatan yang digunakan dalam suatu analisis dan desain adalah pendekatan secara terstruktur. Analisis tersebut adalah pendekatan analisis dengan dimulai dari tahap atas sampai tahap bawah secara sistematis yang menyempurnakan tujuan dan sasara yang telah ada dengan menggunakan metode bertingkat. Suatu pendekatan yang bekerja dari sudut pandang yang lebih tinggi ketingkat yang lebih rinci.

Berdasarkan metoda analisis tersebut model perancangan perangkat lunak yang digunakan yaitu model waterfall. Model ini menuntut suatu pendekatan sistematik - sekuensial dari proses pengembangan perangkat lunak, dimulai pada tingkatan sistem dan dilanjutka dengan analisis , perancangan, pengkodean, uji coba dan pemeliharaan. Model waterfall tersusun atas aktivitas-aktivitas berikut :

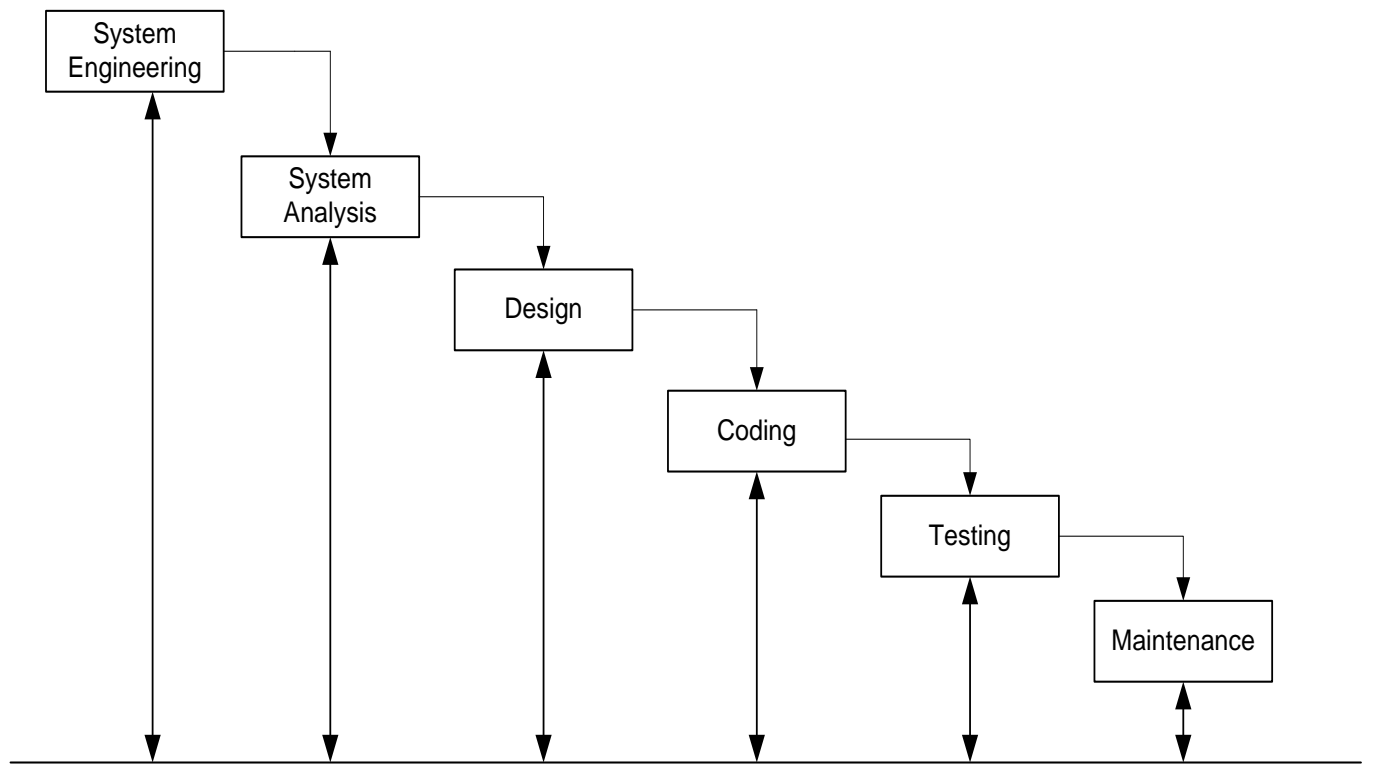

Gambar 3

Metoda waterfall

1. System Engineering, yaitu melaksanakan pengumpulan data dan penetapan kebutuhan semua elemen sistem.

2. System Analysis, yaitu melaksanakan analisis terhadap permasalahan yang dihadapi dan menetapkan kebutuhan perangkat lunak, fungsi perfomansi dan interfacing.

3. Design, yaitu yang menetapkan domain informasi untuk perangkat lunak, fungsi dan interfacing.

4. Coding, yaitu pengkodean yang mengimplementasikan hasil design ke dalam kode atau bahasa yang dimengerti oleh mesin komputer dengan menggunakan bahasa pemograman.
5. Testing, yaitu melaksanakan pengujian kebenaran logik dan fungsionalitas. Disini akan di ketahui kekurangan-kekurangan yang terjadi pada program.

6. Maintenance, yaitu menangani perangkat lunak yang sudah selesai supaya dapat berjalan dan terhindar dari gangguan-gangguan yang menyebabkan kerusakan.

\section{Kebutuhan Perangkat Lunak Dan Perangkat Keras}

\section{Spesifikasi Perangkat Keras}

Hardware adalah peralatan pendukung sisitem komputer yang dapat dilihat serta diraba bendanya. Pengertian 
lain dari perangkat keras adalah semua peralatan yang ada dalam suatu kegiatan pengolahan data. Perangkat keras digunakan untuk mengerjakan fungsifungsi penyiapan data, pemasukan data, perhitungan, penyimpanan, dan pengeluaran (persentasi atau peragaan) hasil. Berikut ini beberapa perangkat keras komputer yang dibutuhkan untuk mengimplementasikan sistem Pakar berbasis web diagnosa gejala kekurangan vitamin.

Hardware untuk pembuatan aplikasi:

1. Komputer PC Pentium IV.

2. Memory 512 Mbytes.

3. Hardisk 40 Gbytes.

4. VGA 128 Mbytes.

Hardware untuk menjalankan aplikasi:

1. Processor Pentium IV.

2. Memory 128 Mbytes, Hardisk 20 Gbytes.

3. Mouse, Keyboard, dan Monitor.

\section{Spesifikasi Perangkat Lunak}

Perangkat lunak atau yang disebut dengan software adalah istilah untuk instruksi-instruksi yang harus dierjakan oleh perangkat keras. Perangkat lunak adalah koleksi atau kumpulan program komputer, yaitu dalam bentuk sistem pengoperasian komputer dan secara terinci dibuat dalam bentuk-bentuk instruksi tertulis dalam bahasa komputer. Perangkat lunak yang mendukung dalam pembuatan program aplikasi ini adalah sebagai berikut :

1. Sistem Operasi Windows XP SP 2.

2. Apache2triad

3. MySQL 5.0

4. Macromedia Dreamweaver MX 8.0

5. Corel Draw 12.

6. Adobe Photoshop

7. PHP coder

8. Mozila Firefox

Sedangkan perangkat lunak untuk menjalankan program aplikasi ini adalah:

1. Windows XP Profesional

2. Apache2triad

3. Mozila Firefox, Google Chrome, Opera

\section{Perancangan Basis Data}

\section{Entity Relationship Diagram}

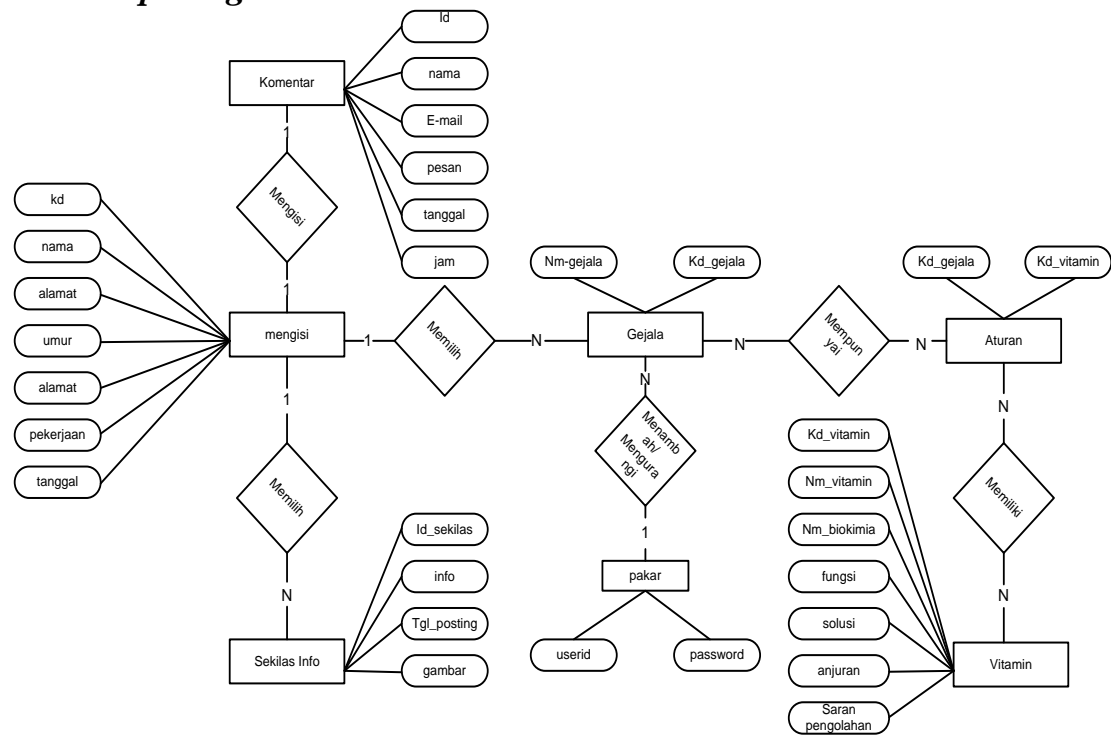

Gambar 4

Entity Relationship Diagram 


\section{Data Dictionary}

Pengunjung : *kd_tamu, nama, kelamin, umur, alamat, pekerjaan, tanggal

Gejala : *kd_gejala, nm_gejala

Aturan : *kd_gejala, kd_vitamin

Vitamin :*kd_vitamin,

nm_vitamin, nm_biokimia, fungsi, solusi anjuran_konsumsi,saran_pengolahan

Komentar : : *id, nama, email, pesan, tanggal, jam

Sekilas Info : $*$ id_sekilas, info, tgl_posting,

$$
\text { Pakar : *user_id, pass_id }
$$

\section{Pemodelan Fungsional}

Pemodelan Fungsional digambarkan dengan perancangan data Flow Diagram. Data Flow Diagram (DFD) menggambarkan aliran data sumber, tujuan, penyimpanan data, dan prosesproses yang dilakukan terhadap data yang mana proses-proses sebagai node-node dan aliran logik data sebagai penghubung antara node-node tersebut. Tujuan dari perancangan ini adalah untuk menghasilkan sebuah model atau representasi dari entitas, proses, data dan sistem yang dibangun.

\section{Diagram Konteks}

Diagram konteks adalah arus data yang berfungsi untuk menggambarkan ketertarikan aliran-aliran data antara sistem dengan bagian-bagian luar (kesatuan luar). Kesatuan luar ini merupakan sumber arus data atau tujuan data yang berhubungan dengan sistem informasi tersebut. Diagram konteks memberikan batasan yang jelas mengenai besaran-besaran entitas yang yang berada di luar sistem yang sedang dibuat, artinya diagram ini menggambarkan secara jelas batasan-batasan dari sebuah sistem yang sedang dibuat.

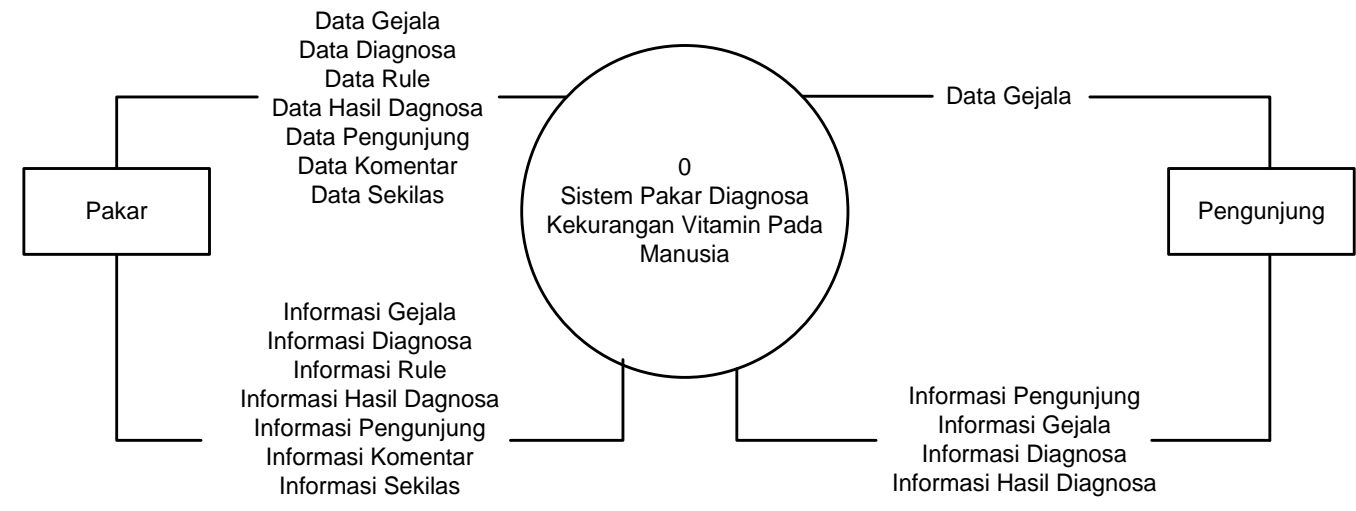

Gambar 5

Diagram Konteks 


\section{Data Flow Diagram}

1. Level 1

DFD Level 1 merupakan pengembangan dari Diagram Konteks yang menggambarkan secara lebih terperinci mengenai sistem yang akan dibuat.
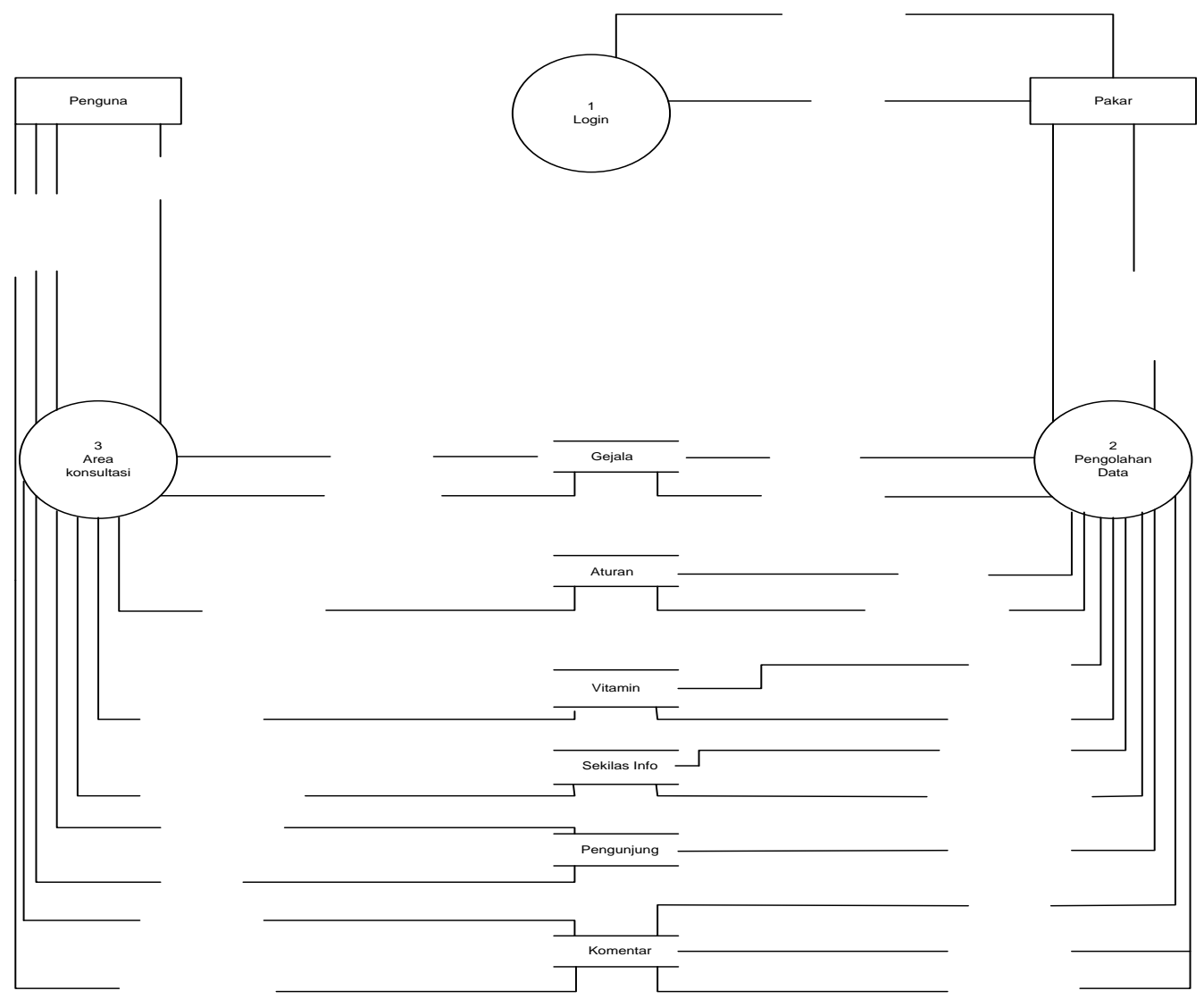

Gambar 6

Level 1

2. Level 2 Proses Untuk Login Pakar
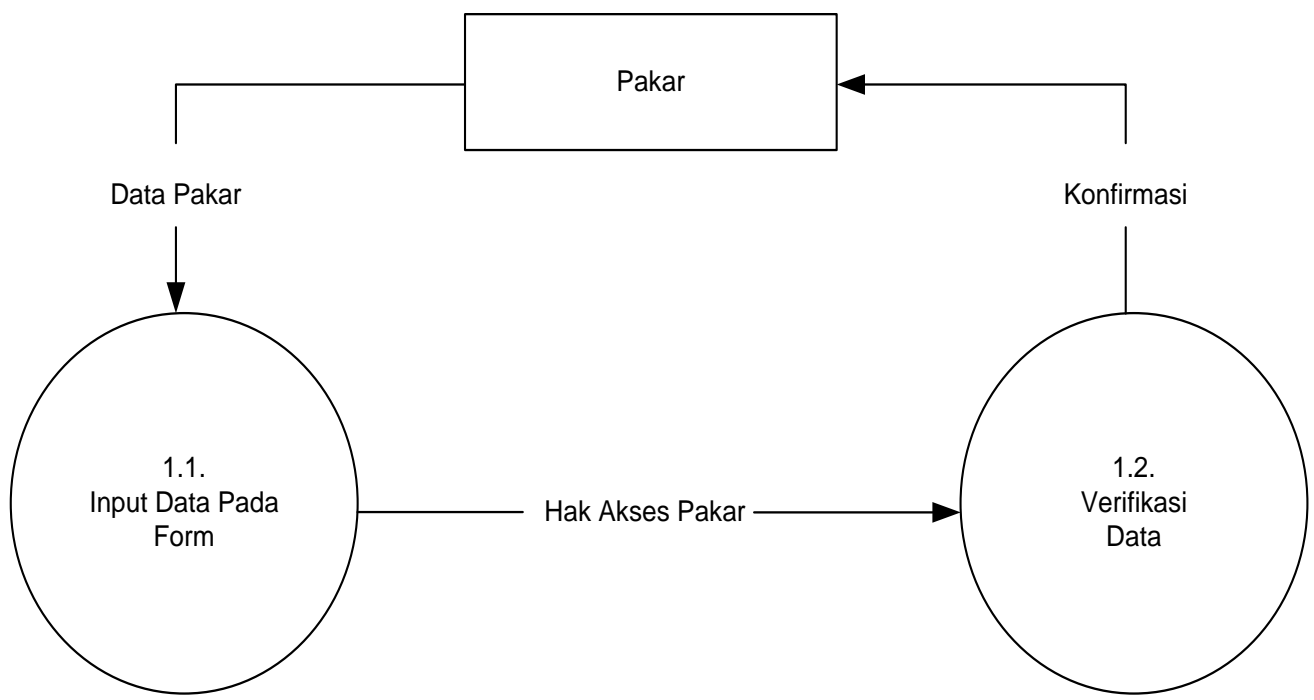

Gambar 7

Level 2 Proses Untuk Login Pakar 


\section{Level 2 Proses Untuk Pongolahan Data Pakar}

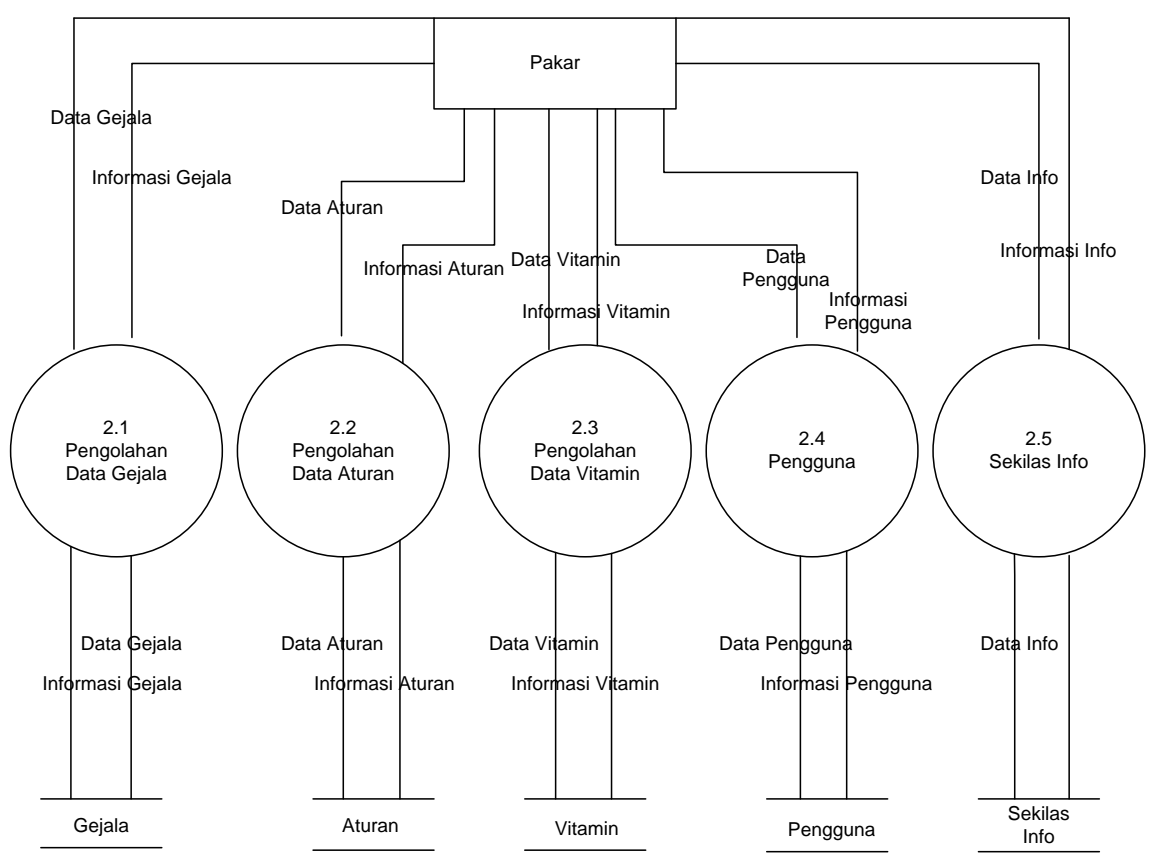

Gambar 8

Level 2 Proses Untuk Pongolahan Data Pakar

4. Level 2 Proses Untuk Pengolahan Data Pengguna

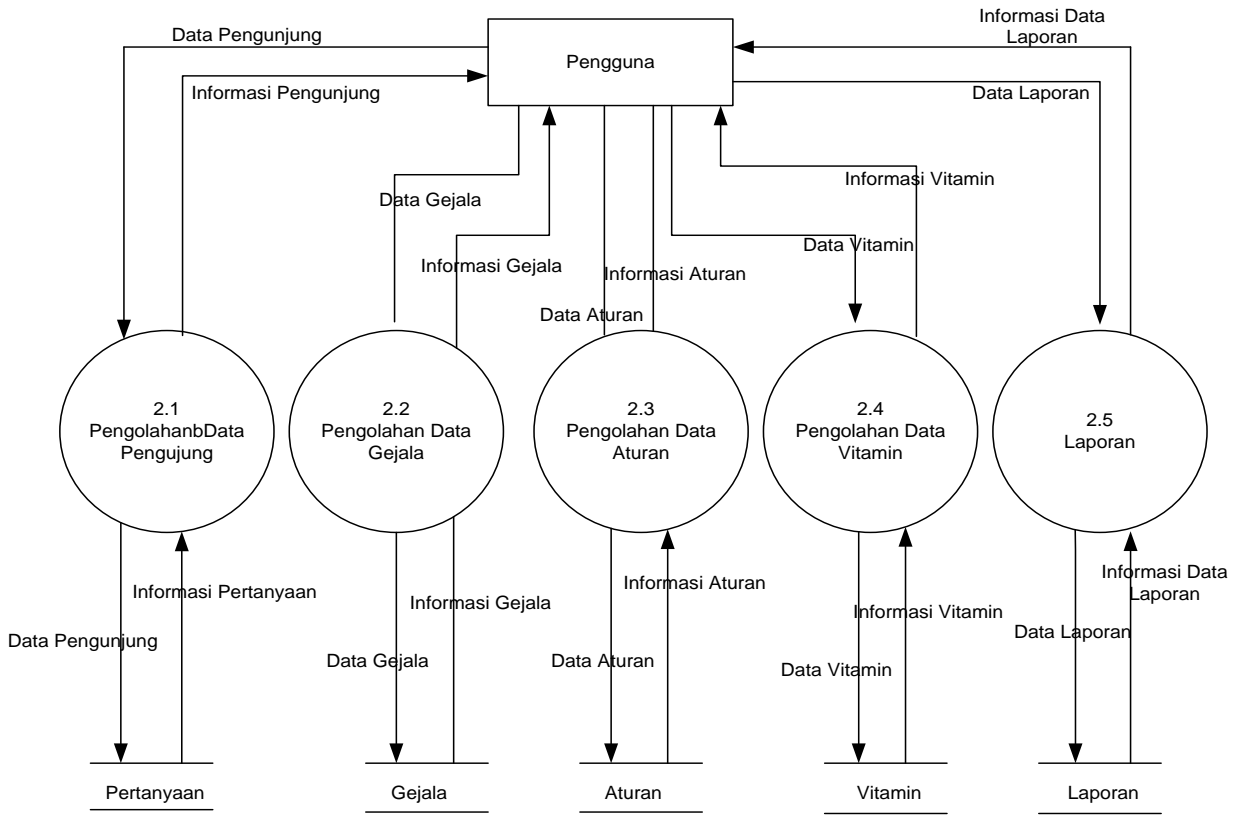

Gambar 9

Level 2 Proses Untuk Pengolahan Data Pengguna 


\section{Perancangan Arsitektur}

Setelah melalui tahapan-tahapan proses yang dilakukan pada perancangan arsitektur yaitu mengubah aliran informasi (yang dipersentasikan dengan DFD) menjadi struktur perangkat lunak. Struktur program merupakan suatu gambaran yang dibuat untuk mengidentifikasi dan mengilustrasikan sistem yang akan dibuat dalam bentuk model-model. Perancangan struktur program yang dibuat dimaksudkan untukmenggambarkan modul-modul yang menyusun sistem dam menggambarkan hirarki kontrol diantara modul-modul tersebut. Struktur program hassil perancangan berikut :
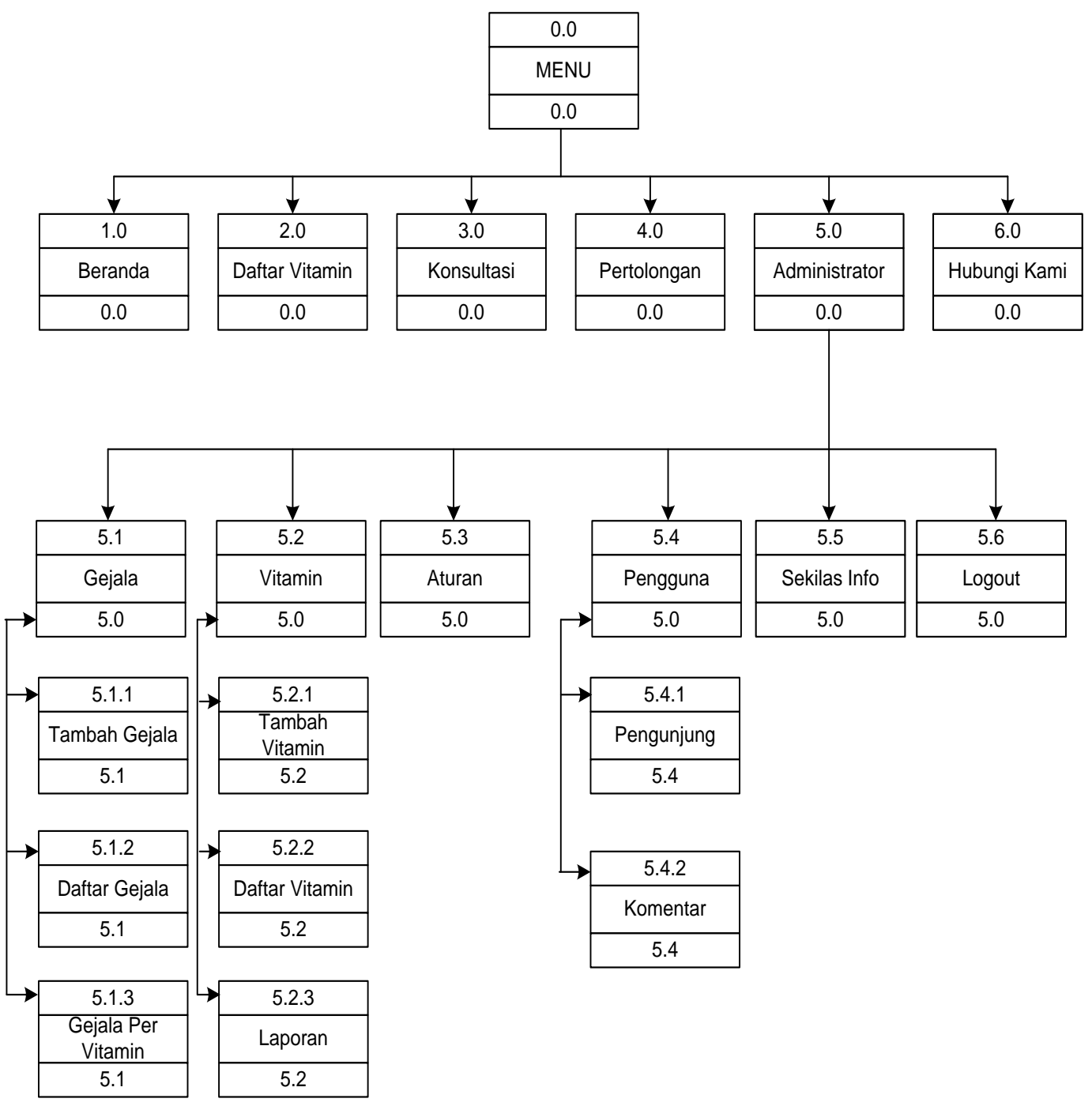

Gambar 10

Perancangan Arsitektur 


\section{Perancangan Antar Muka}

\section{Perancangan Area Pengembang}

1. Form Login Administrator

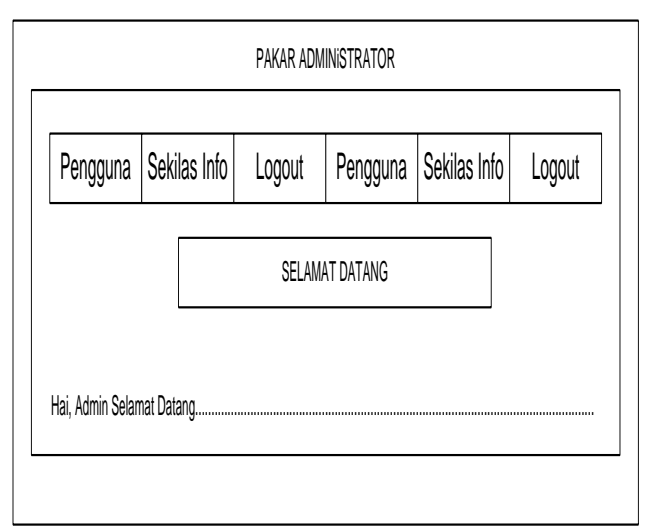

Gambar 11

Form Login Administrator

2. Form Tambah Gejala

Kekurangan Vitamin

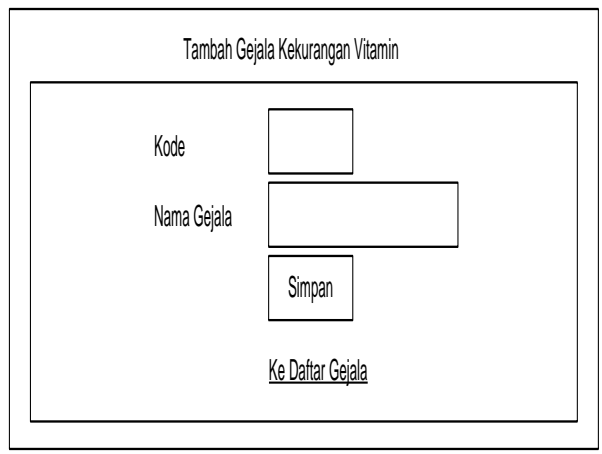

Gambar 12

Form Tambah Gejala Kekurangan Vitamin

3. Form Daftar Semua Gejala

Kekurangan Vitamin

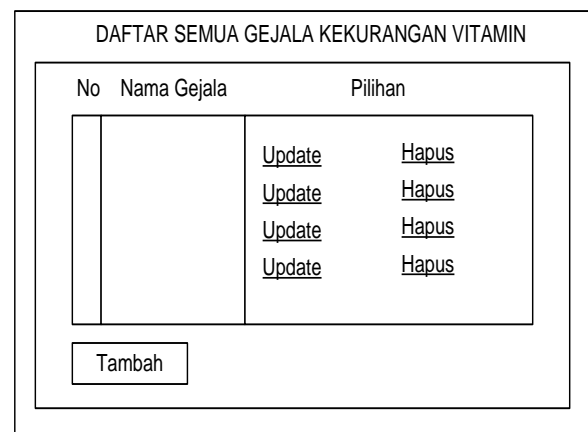

Gambar 13

Form Daftar Semua Gejala

Kekurangan Vitamin
4. Form Tampilan Gejala Per Vitamin

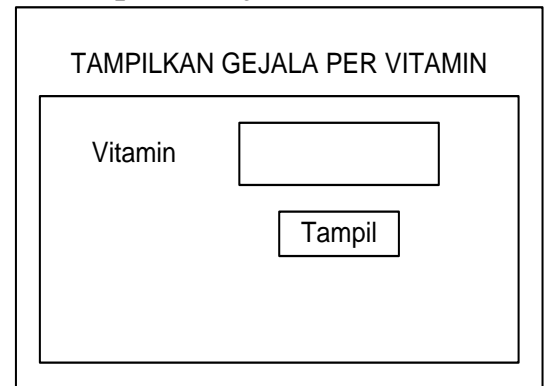

Gambar 14

Form Gambar Gejala Pervitamin

5. Form Tampilan Gejala Per Vitamin Setelah Dipilih

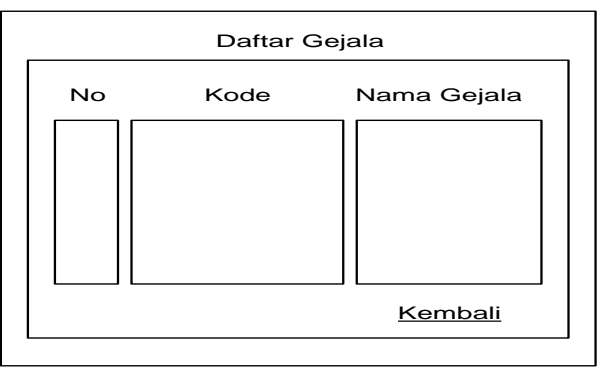

Gambar 15

Form Gejala Per Vitamin Setelah Dipilih

6. Form Tambah Vitamin

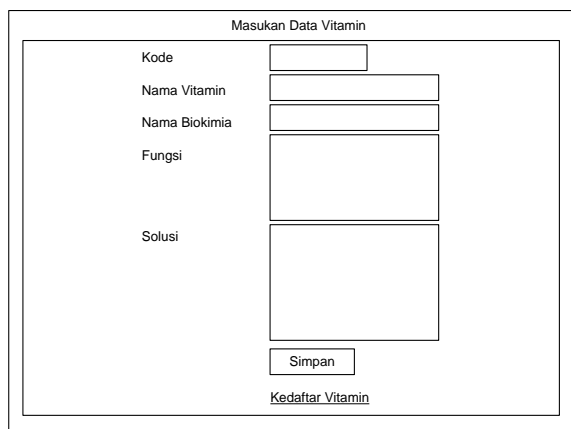

Gambar 16

Form Tambah Vitamin

\section{Form Daftar Vitamin}

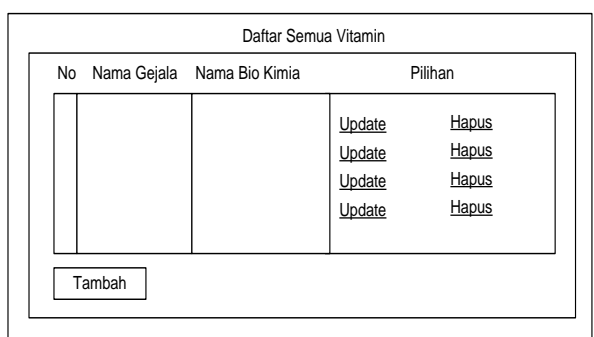

Gambar 17

Form Daftar Vitamin 


\section{PEMBAHASAN}

\section{Hasil Implementasi}

\section{Aplikasi Sistem Pakar}

Aplikasi sistem pakar untuk mendiagnosa kekurangan vitamin pada tubuh manusia adalah sebuah perangkat lunak yang dapat memberikan informasi mengenai diagnosa kekurangan vitamin pada tubuh manusia.

Secara garis besar aplikasi mendiagnosa kekurangan vitamin pada tubuh manusia dibuat dengan tuntutan untuk melakukan tugas mengambil datadata hasil konsultasi pengguna, memasukan dan membandingkan datadata tersebut ke dalam aturan yang telah di tuliskan dalam basis pengetahuan, kemudian menampilkan hasil analisa kekurangan vitamin berdasarkan kesimpulan yang didapat. Output dari sistem pakar untuk solusi dari kekurangan vitamin tersebut.

\section{Interaksi Aplikasi Dengan Pengguna}

Aplikasi sistem pakar diagnosa kekurangan vitamin merupakan media konsultasi pengguna untuk mengetahui kekurangan vitamin berdasarkan gejala yang ditimbulkan. Untuk itu pada area konsultasi, pengguna dapat menandai gejala yang ditimbulkan kemudian aplikasi ini akan memproses data-data tersebut sampai memberikan informasi hasil pendiagnosaan berupa solusi, anjuran, saran pengolahan dari kekurangan vitamin tersebut.

Seorang pakar memiliki hak akses untuk entri item gejala, entri aturan, perubahan item gejala, perubahan item aturan, perubahan data vitamin, menghapus data pengguna yang terdiri dari pengunjung, dan komentar, menambahkan dan menghapus sekilas info.

\section{Tampilan Aplikasi Sistem Pakar}

\section{Form Menu Sistem Pakar}

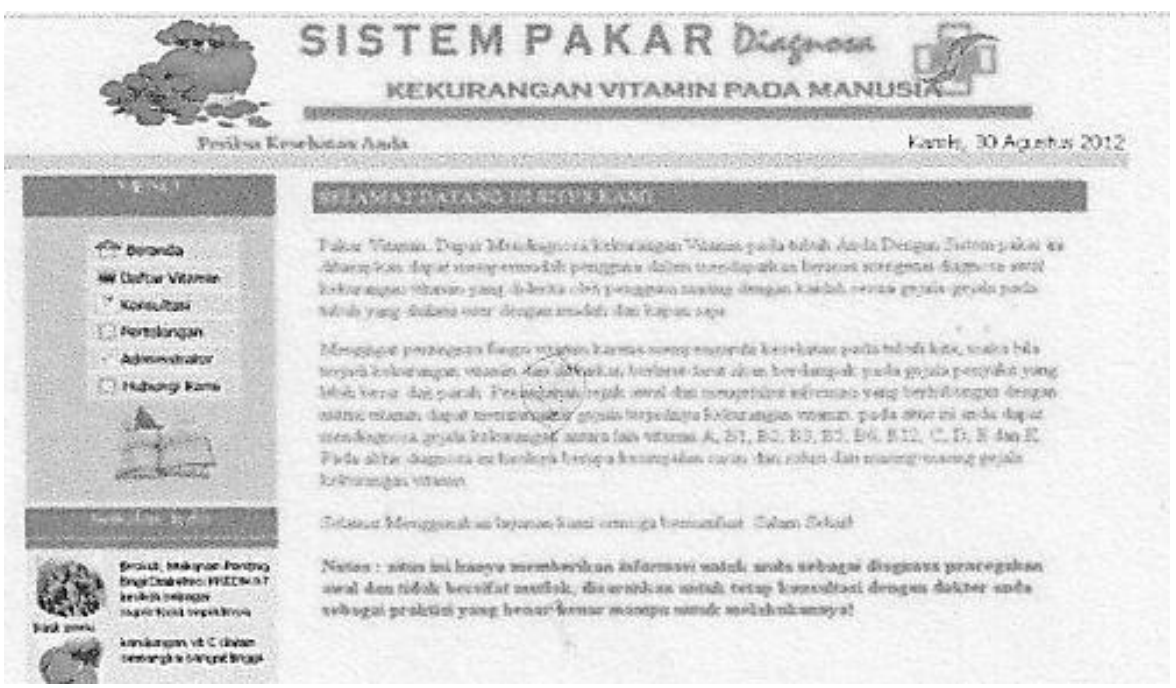

Gambar 18

Form Menu Sistem Pakar

Pada tampilan awal menu utama, kita akan dihadapkan pada beberapa pilihan menu yaitu beranda, daftar vitamin, konsultasi, pertolongan, administrator dan hubungi kami. Untuk menu administrator terdapat autentifikasi yang hanya diketahui oleh admin saja. 


\section{Form Login}

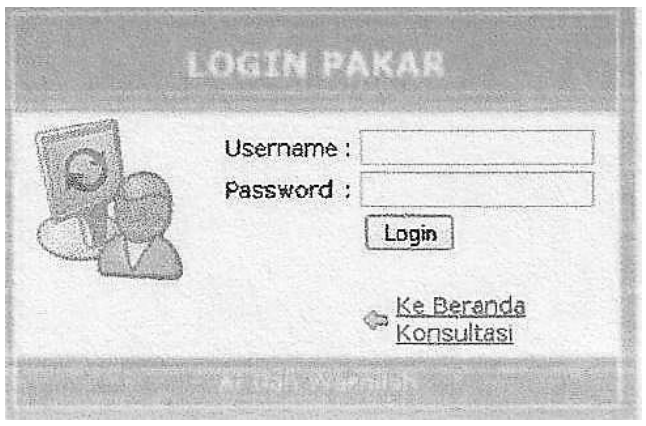

Gambar 19

Form Login

Form login bertujuan verifikasi keamanan untuk seorang administrator sistem dan merupakan jalur untuk memasuki hak akses pakar. Apabila login berhasil maka akan masuk ke form pakar yang terdiri dari menu gejala, vitamin, aturan, pengguna, sekilas info dan logout seperti dilihat pada gambar 19.

\section{Form Menu Pakar}

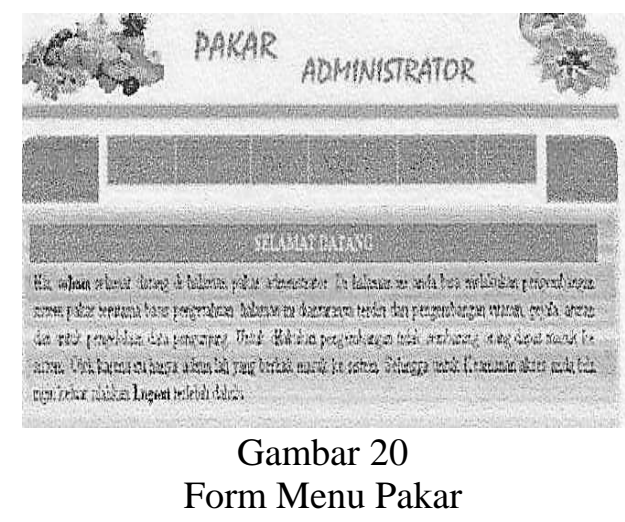

4. Form Tambah Gejala

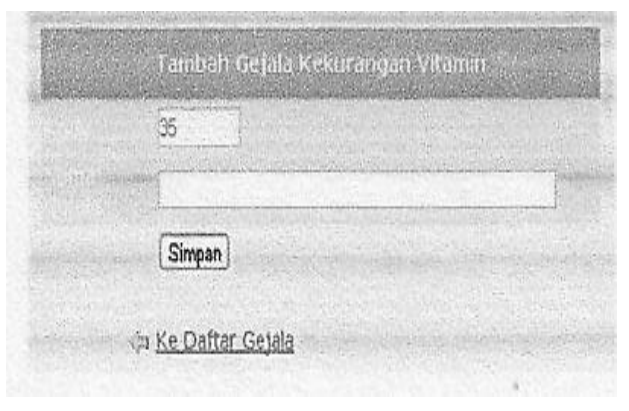

Gambar 21

Form Tambah Gejala
Form tambah gejala merupakan form pengolahan data gejala, untuk fasilitas penambahan gejala dan menyimpan ka daftar gejala.

\section{PEMBAHASAN}

\section{Pengujian Aplikasi Sistem Pakar}

Tahap ini merupakan tahap akhir dalam pengembangan sistem. Sistem yang telah selesai dibuat akan diuji terlebih dahulu sebelum siap digunakan oleh pengguna.

Tujuan utama pengujian sistem pakar adalah benar atau tidaknya keluaran sistem dan mengetahui apakah sistem yang sudah mewakili pakar dengan keahlian dan pengetahuan yang penambahan informasi serta perbaikan sesuai dengan kebutuhan.

\section{Pengujian Proses Login Pakar}

Untuk masuk ke dalam sistem, seorang pakar harus terlebih dahulu memasukan identitas berupa user name dan password sesuai hak aksesnya dengan tujuan keamanan data lebih terjamin. Jika proses verifikasi user name dan password dibiarkan kosong dan salah maka akan tampil konfirmasi salah password. Dan jika login pakar berhasil maka akan masuk ke form pakar yang terdiri dari menu memanipulasi gejala, vitamin, aturan, sekilas info, menghapus data pengunjung dan komentar.

\section{Pengujian Pakar}

$$
\text { Pengujian pakar merupakan }
$$
pengujian pada sub menu basis pengetahuan. Sub menu basis pengetahuan antara lain : entri item pertanyaan, hapus dan edit petanyaan. Dalam basis pengetahuan tersebut terdapat proses modifikasi (tambah,edit dan hapus) dari tiap pengetahuan yang dipresentasikan dalam tabel. Setelah sub menu pengetahuan selanjutnya terdapat fasilitas untuk memodifikasi basis aturan dan penjelasan.

Pengujian pada Form Entri Item gejala dan Form Edit dan Hapus gejala, 
dimulai dari fungsi tombol simpan. Tombol simpan merupakan tombol pengeksekusian data untuk di simpan pada basis data. Pengujian pada suatu susunan kombinasi jawaban dapat memberikan nilai yang sesuai dengan nilai premis yang benar dari suatu aturan.

\section{PENUTUP}

Ada beberapa kesimpulan dan saran yang dapat disampaikan penulis sebagai hasil dari evaluasi sistem pakar dalam penelitian ini

\section{Kesimpulan}

Dari hasil evaluasi sistem pakar ini, dapat disimpulkan:

1. Sistem pakar membantu dalam pemecahan masalah secara otomatisas tanpa bantuan seorang pakar. Sistem pakar yang dibahas disini adalah sistem pakar berbasis web ini untuk mendiagnosa kekurangan vitamin pada tubuh manusia yang dapat menbantu seorang pengguna untuk berkonsultasi dengan sistem seputar diagnosa gejala kekurangan vitamin. Sehingga nantinya akan ditampilkan konklusi dan solusi dari permasalahan yang dialami pengguna.

2. Aplikasi sistem pakar (Expert System) yang dibuat dengan menggunakan proses penelusuran maju (Forward Chaining) mampu mengenali jenis kekurangan vitamin pada tubuh manusia, antara lain vitamin A, B1, B2, B3, B5, B6, B12, $\mathrm{C}, \mathrm{D}, \mathrm{E}$ dan $\mathrm{K}$.

3. Dengan adanya sistem pakar ini, bisa mempermudah orang mendapatkan pelayanan informasi diagnosa kekurangan vitamin pada tubuh untuk pencegahan awal sebelum orang datang ke dokter ahli, karena konsultasi menggunakan sistem ini dapat dilakukan kapan dan dimana saja, hasilnya lebih cepat dengan biaya yang lebih hemat.

\section{Saran}

Setelah pengembangan sistem pakar ini dilakukan, ada beberapa saran yang harus diterapkan dalam pengembangan sistem pakar.

1. Pengumpulan data yang lebih banyak dan lebih akurat guna penyempurnaan mesin inferensi dengan penambahan variabelvariabel baru yang bersangkutan dengan hal-hal yang berpengaruh dengan vitamin.

2. Perlu ditambahkan data berupa ciriciri dari gejala kekurangan vitamin, organ-organ tubuh yang terkena kekurangan vitamin agar hasil identifikasi lebih jelas.

3. Lengkapi data-data dengan gambar untuk memperjelas informasi

4. Perlu dilakukan penelitian lebih lanjut untuk menentukan nilai $\mathrm{CF}$ (Certainty Faktor) supaya nilai kepastian yang dihasilkan lebih tepat.

\section{REFERENSI}

Abdul Kadir. 2003.Dasar Pemrograman Web Dinamis Mengggunakan PHP. Yogyakarta : Andi

Almatsier,Sunita.2004. Prinsip Dasar Ilmu Gizi. Jakarta: Gramedia.

Bachtiar,Agus.2008.PHP Script Most Wanted. Yogyakarta: Andi Offset.

Devi,Nirmala. 2010. Nutrition and Food Gizi Untuk Keluarga. Jakarta: Kompas.

Hadi,Mulya.2009. Dreamweaver CS4 untuk orang awam.

Palembang:Maxikom.

Hakim,Lukmanul.2010. Bikin Website Super keren dengan PHP dan jQuery. Yogyakarta:Lokomedia.

Hartono,Jogiyanto.2005. Analisa dan Desain Sistem Informasi Edisi III. Yogyakarta: Andi Offset. 
Haryanto.2002. Membuat Data Base dengan Microsoft Acces. Bandung: Informatika.

Kusumadewi,Sri.2003. Artificial Intelegence (Teknik dan Aplikasinya). Yogyakarta:Graha Ilmu.

Kusrini.2008.Aplikasi Sistem Pakar Menentukan Faktor Kepastian Pengguna Dengan Metode Kuantifikasi Pertanyaan. Yogyakarta: Andi Offset.

Nugroho,Bunafit.2008.Membangun Aplikasi Sistem Pakar dengan PHP dan Editor Dreamweaver.

Yogyakarta:Gava Media.

Nugroho,Bunafit.2009.Aplikasi

Pemrograman Web Dinamis dengan PHP dan MySQL. Yogyakarta:Gava Media.

Pressman,Ph.D,Roger S. Rekayasa Perangkat Lunak (Pendekatan Praktisi) Edisi 7, Yogyakarta:Andi Publisher. 